\title{
The use of orthophoto map for soils mapping of dwindling lakes catchment areas: a case study of Sumowskie Lake, NE Poland
}

\author{
Łukasz Mendyk, Maciej Markiewicz, Marcin Świtoniak, Renata Bednarek
}

Faculty of Earth Sciences, Nicolaus Copernicus University

Lwowska 1, 87-100 Toruń, Poland

e-mail: mendyk.geo@gmail.com

\begin{abstract}
The aim of the study was to assess the suitability of aerial photos for mapping the soils of dwindling lakes catchment areas The study area is located in the North Poland, within the Brodnica Lakeland and it includes the direct catchment area of dwindling Sumowskie Lakes. There were three test area established for soil mapping. The photointerpretation was based on both immediate properties (colour of topsoil) for ploughed cultivated fields, and intermediate properties (vegetation and relief) for the areas of forests, shrubs or permanent pasture. The obtained results confirm the high usability of the cartographic materials such as aerial photographs and topographic maps for studies on specifications of areas such as the vicinities of dwindling lakes.
\end{abstract}

Key words: dwindling lakes, soils, soil mapping, orthophoto maps, aerial photographs

\section{Introduction}

The use of aerial photographs in the soil science investigations creates some difficulties since the soils are hindered from the observations under various land cover elements, which as a rule are comprised of natural or cultivated vegetation (Smirnow 1970; Furmańczyk 1980; Ciołkosz et al. 1999; McBratney et al. 2003). The best conditions to perform a photointerpretation of soils occur when they are not or are only slightly covered with vegetation, which demands taking the photographs in strictly defined time limits (Ciołkosz et al. 1999). The soils, as one of the elements of the natural environment, are however interpretable based on intermediate properties. The most important of these include: relief, vegetation, hydrographic features, and type of human management and anthropogenic components of the landforms (Fuller et al. 2005). The knowledge of relationships between these environmental components enables relevant specification of selected soil properties (Białousz 1999).
Mapping of soils based on the intermediate properties is applicable for specific areas, which by their nature are constantly covered with various kinds of vegetation. Such areas include the surroundings of dwindling lakes. The problem of dwindling lakes affects a large portion of the water bodies of North Poland. Within this region, it is estimated that from the last glaciation, a half of lakes have vanished (Kalinowska 1961; Marszelewski 2005). The consequence of this process is the evolution of many different environmental elements in the vicinities of dwindling water bodies, including the soils that are very good and relatively quick to respond indicators of any environmental changes. The changes affect not only those soils which are closely related to high levels of ground waters, i.e. hydrogenic and semihydrogenic ones, but also autogenic soils occurring in the immediate vicinity of those water bodies. Many of these changes are adverse, which leads to both physical and chemical degradation of soils, and consequently also decrease their value in use. These are also the areas of generation of completely new soils, originating from the exposed lacustrine sediments, which also undergo 
further evolution dependant on their dehydration. The existence and development of specific soils within the bottom areas of dwindling Sumowskie Lakes find confirmation in the investigations of i.a. Gonet et al. (2010).

The purpose of the study is to assess the suitability of aerial photos for mapping the soils of dwindling lakes catchment areas. After the preliminary analysis of available cartographic materials and completed field studies, the aerial photographs served as one of the basic information sources for the development of the map of the Sumowskie Lakes catchment area. The photointerpretation was based on both immediate properties for ploughed cultivated fields, and intermediate properties for the areas of forests, shrubs or permanent pasture.

\section{Study area}

The study area is located in the North East Poland, within the Brodnica Lakeland, (Fig. 1). It includes the direct catchment area of dwindling Sumowskie Lakes and the sub-catchment area of minor watercourse flowing out to the north. According to Richling and Dąbrowski (2005), the landforms of this area are natural ones, rated to the class of lowland landforms, kind of glacial landscape, and hilly type.
The glacial relief of the study area is very diversified. It comprises features related to the subglacial deposition - ground moraines, landforms connected to the effect of glacial melt waters - esker and topography related to stagnant and melting of dead ice blocks, such as kame hills as well as vast kettle holes (Niewiarowski 1995).

The hydrographic network in the study area and surroundings is very complex. The total length of the watercourses and ditches is about $54 \mathrm{~km}$, i.e $2.9 \mathrm{~km} / \mathrm{km}^{2}$. However, this is largely the case due to land improvement works carried out. In the designated catchment area, there are five water bodies of more than 1 ha of total surface area. These are the Sumowskie Lakes and three water reservoirs located to the east. In total, these waters cover 33.7 ha, which is ca. $1,8 \%$ of the catchment surface area (calculations made in ArcGIS 9.3). In addition to the above listed water reservoirs, there are also considerable numbers of kettle hole, smaller than 1 ha, grouped in majority to the south-east from the Sumowskie Lakes, within the area of undulated till plain.

The Sumowskie Lakes are kettle water reservoirs; a single basin in the past. The water level of the former Sumowskie Lake has fallen due to natural and anthropogenic processes, forming two separate basins (Marszelewski 2005). The surface area of the larger, northern lake is about 15.1 ha, while the smaller, southern amounts to ca. 10.3 ha.

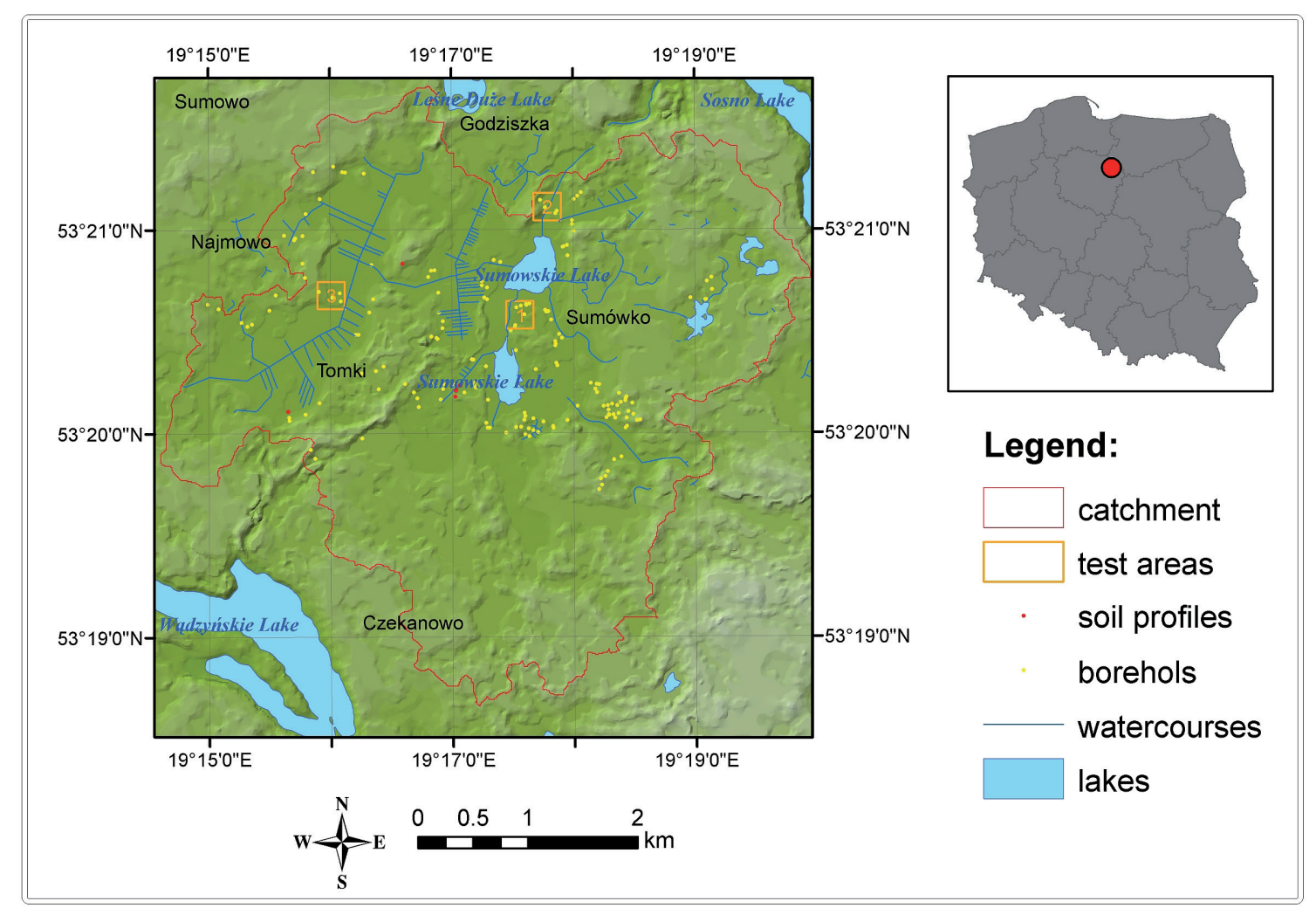

Figure 1. Location of the study area 
The shoreline lengths are respectively, $1.7 \mathrm{~km}$ and $1.8 \mathrm{~km}$ (calculations made in ArcGIS 9.3). The average depth of the northern lake is ca. $1.2 \mathrm{~m}$. Both basins are strongly eutrophicated, their shorelines entirety fall into marsh type, covered with emergent vegetation. With respect to fishing, they are classified as carp lakes. This supports a considerable extent eutrophication of both lakes (Burak 1994; Burak et al. 2005a).

Within the Brodnica Lakeland, the prevailing plant communities are deciduous forests. However, among the forest communities, the most widespread are mixed coniferous forests formed by effect of persistent pine growing on poor soils (Ceynowa-Giełdon 1984). Zielski (1978) distinguished seven communities within the lakeland. Beside above-mentioned mixed coniferous forests Pino-Quercetum, they include: Salicetum pentandro-cinereae - willow shrubs, Carici elongate-Alnetum - alder forest, Circaeo-Alnetum - ash-alder riparian forest, Fraxino-Ulmetum - hardwood alluvial forest, Tilio-Carpinetum - broadleaved forest, Potentillo albae-Quercetum - light oak forest. Moreover he distinguished one forest edge shrub community of Prunetalia order.

\section{Materials and methods}

Three study sites were selected for the tests, ca. $250 \times 250$ $\mathrm{m}$, located in the direct catchment area of dwindling Sumowskie Lakes (Fig. 1). The reason for the study sites selection was considerable diversity of the vegetation covering the land within the catchment area. They include forest areas, rush with willow shrubs and the agricultural areas - arable lands and permanent pastures.

The mapping of soils involved use of the aerial photos (photos in the visible spectrum, natural colours). The references for verification of the cartographic soil units were soil-agricultural maps (both analogue and digital ones) featuring scale of 1:25 000, topographic maps, scale 1:10 000, and detailed geological maps, scale 1:50 000.

The field works involved over 130 boreholes, depths from 0.5 to 3 metres and 6 soil pits. The photointerpretation was based on both immediate properties (e.g. colour of topsoil) for ploughed cultivated fields, and intermediate properties (plant cover) for the areas of forest, shrubs or permanent pastures. The soil samples taken from the profiles were brought to the Department of Soil Science and Landscape Management, NCU. The estimations using the samples included the following (van Reeuwijk 2006):

- nitrogen content by the Kjeldahl method,

- organic carbon content by the Alten method and Tiurin method,

- $\mathrm{pH}$ by potentiometric method in water and $\mathrm{KCl}$ solution,
- the texture by the sieve method and the Bouyoucos areometric method in the modification of Casagrande and Prószyński; the results were used for the estimation of the grain size group.

The morphology of the soil profiles and the results of laboratory analyses are presented in Table 1.

For study sites no. 1 and 2, an additional information on the vegetation cover provided the map of vegetation communities developed by A. Dziamski from Department of Botany and Ecology, University of Technology and Life Sciences in Bydgoszcz (unreported materials). The analysis of area no. 3 considered the information from the Taxation Descriptions by the Brodnica Forest Office, District Zbiczno, acquired from the Regional Directorate of State Forests in Toruń.

\section{Results}

The soil cover of the Sumowskie Lakes catchment area features very high diversity. Pursuant to the classification of the soil cover structure types according to Bednarek and Prusinkiewicz (1997), it demonstrates irregularly spotty type of the soil cover structure.

The 19 cartographic units were designated on the whole area. They include the ranges of individual soil units or associations of those. The study sites are located in the centre of the investigated area, where organic soils prevail produced of peats and gyttjas, covering the bottoms of the vast kettle holes in the villages of Sumówko and Tomki (Fig. 2). The material of utmost interest were specific gyttja-moorsh soils originated from lacustrine sediments. They co-exist in associations with peat-moorsh soils within the limits of the former bottoms of the Sumowskie Lakes. The soils derived from lake sediments are characterized by a high content of organic matter and slightly acidic or near neutral reaction (Tab. 1, Fig. 3).

The soil on the outskirts of the former lake basin often are covered with different thickness of the colluvial material, resulting from intensive agriculture (anthropogenic denudation).The hydrogenic soils neighbour with autogenic ones - rusty soils, lessive soils, arenosols, and pararendzinas. These soils contain a small amount of organic matter and are characterized by variable reactivity compared to soils derived from lake sediments (Tab. 1, Fig. 3). They developed from sandy sediments consisting of kame hills and esker near Tomki and till composing of a ground moraine. These forms tower over the bottom of the kettle hole (Szczegółowa Mapa Geologiczna Polski 1:50 000, sheet no. 285.0 Brodnica and no. 247.0 Skrwilno). 


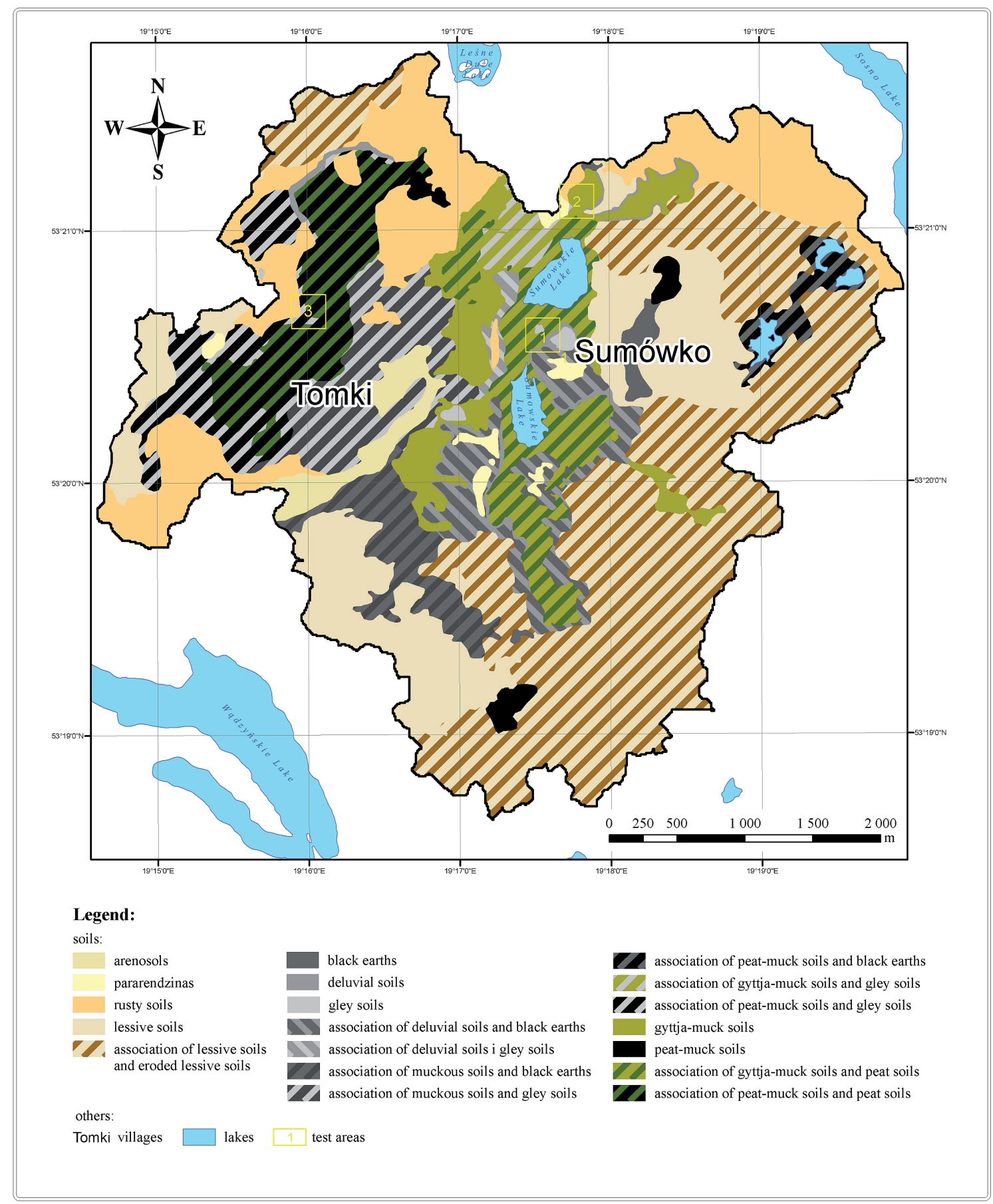

Figure 2. Soil cover of Sumowskie Lakes catchment area 
Table 1. Some of physical and chemical properties of examined soils

\begin{tabular}{|c|c|c|c|c|c|c|}
\hline \multirow{2}{*}{$\begin{array}{l}\text { Genetic horizon } \\
\text { acc. to PTG } 1989\end{array}$} & \multirow{2}{*}{$\begin{array}{l}\text { Depth } \\
{[\mathrm{cm}]}\end{array}$} & \multirow{2}{*}{$\% \mathrm{OM}$} & \multirow{2}{*}{$\mathrm{C}: \mathrm{N}$} & \multicolumn{2}{|c|}{$\mathrm{pH}$} & \multirow{2}{*}{ Texture acc. to USDA } \\
\hline & & & & $\mathrm{H}_{2} \mathrm{O}$ & $\mathrm{KCl}$ & \\
\hline \multicolumn{7}{|c|}{ Deluvial soil } \\
\hline Adelp & $0-30$ & 6.88 & 12 & 7.5 & 7.0 & sandy loam \\
\hline Adel & $30-60$ & 9.52 & 13 & 7.4 & 6.9 & sandy loam \\
\hline \multicolumn{7}{|c|}{ Peat-muck soil } \\
\hline $\mathrm{Ol}$ & $2-0$ & 95.2 & 24 & 5.2 & 4.8 & - \\
\hline M & $0-12$ & 57.6 & 13 & 4.1 & 3.5 & - \\
\hline Otnisz1 & $12-42$ & 89.4 & 15 & 5.8 & 5.4 & - \\
\hline Otnisz2 & $42-56$ & 99.2 & 15 & 6.3 & 5.9 & - \\
\hline Otnisz3 & $56-150$ & 96.2 & 16 & 6.4 & 5.9 & - \\
\hline $\mathrm{D}$ & $150-(170)$ & 1.35 & 18 & 3.7 & 3.8 & sand \\
\hline \multicolumn{7}{|c|}{ Gyttja-muck soil } \\
\hline $\mathrm{AO}$ & $0-40$ & 19.3 & 17 & 6.3 & 6.1 & sand \\
\hline Mt & $40-60$ & 84.6 & 16 & 6.0 & 5.7 & - \\
\hline Ogyca & $60-120$ & 28.8 & 14 & 8.0 & 7.8 & - \\
\hline $\mathrm{D}$ & $120-(140)$ & 1.31 & 15 & 7.8 & 7.3 & loam \\
\hline \multicolumn{7}{|c|}{ Gleyed black earth } \\
\hline Ap & $0-28$ & 3.94 & 12 & 7.8 & 7.2 & loam \\
\hline Gca (loam) & $28-(60)$ & 0.89 & 12 & 8.3 & 7.3 & loam \\
\hline Gca (sand) & $28-(60)$ & 0.23 & 11 & 8.6 & 8.0 & sand \\
\hline \multicolumn{7}{|c|}{ Initial pararendzina } \\
\hline Acap & $0-24$ & 0.86 & 10 & 8.1 & 7.6 & sandy loam \\
\hline Ccal & $24-40$ & 0.14 & 12 & 8.7 & 7.9 & sand \\
\hline Wca & $40-45$ & 0.50 & 18 & 8.5 & 8.1 & sandy loam \\
\hline $\mathrm{Cca} 2$ & $45-65$ & 0.12 & 9 & 8.6 & 7.9 & sand \\
\hline $\mathrm{Cca} 3$ & $65-80$ & 0.17 & 17 & 8.4 & 7.9 & sand \\
\hline $\mathrm{Cca} 4$ & 80-(95) & 0.06 & 15 & 8.8 & 8.1 & sand \\
\hline \multicolumn{7}{|c|}{ Rusty soil } \\
\hline $\mathrm{Ol}$ & $1,5-1$ & 99.2 & 77 & 4.4 & 3.8 & - \\
\hline Ofh & $1-0$ & 57.2 & 32 & 4.6 & 3.7 & - \\
\hline$A(p)$ & $0-40$ & 0.86 & 14 & 6 & 4.6 & sand \\
\hline $\mathrm{Bv}$ & $40-90$ & 0.14 & 15 & 8.4 & 7.6 & sand \\
\hline $\mathrm{C}$ & $90-100$ & 0.50 & n.o. & 9.1 & 8.7 & sand \\
\hline
\end{tabular}



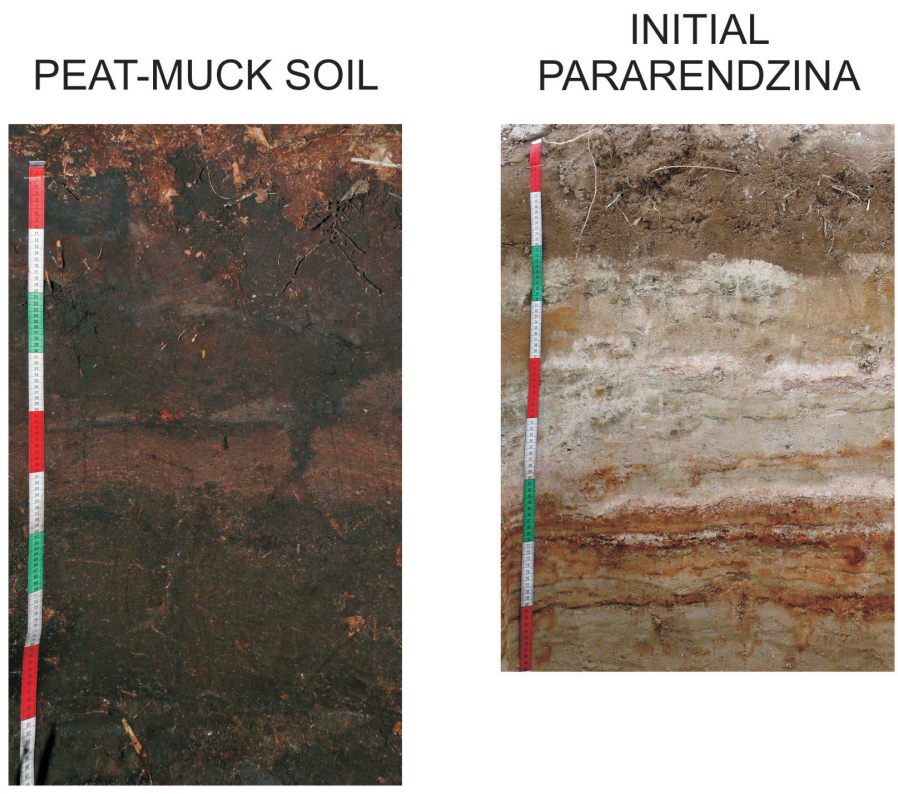

\section{GLEYED BLACK EARTH}

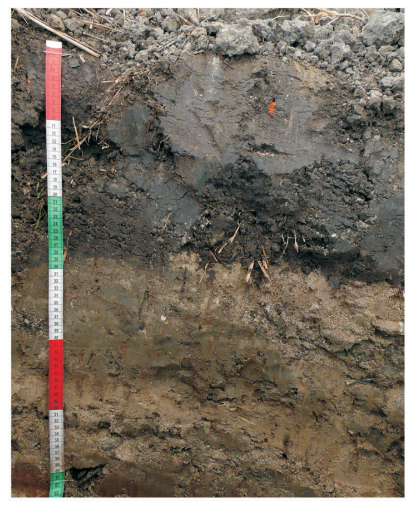

Figure 3. Morphology of some of the investigated soils

\section{Study site 1}

This site is located in the central part the direct catchment area of Sumowskie Lakes (Fig. 1). Contains part of the former lacustrine bottom, where gyttja-moorsh and peatmoorsh and peat soils developed (Fig. 3). They originated from shallow water lacustrine sediments such as gyttjas and peats.

They are mainly covered by natural vegetation, arranged in rush communities mosaic (Phragmitetum australis) occurring in gyttja soils and willow shrubs (Salicetum pentandro-cinereae) primarily growing on peat soils. At the edges of the hydrogenic soil patches, where they are dehydrated to the largest extent, there occur meadow communities such as Arrhenatheretum elatioris or Lolio-Cynosuretum (Fig. 4). Found in places, sandy mineral islands are represented by gley soils, while the hills made of glaciolacustrine sediments surrounding the former water body feature occurrence of arenosols, and deluvial soils at their bases. The above listed mineral soils cover the meadow communities identical with the ones that cover the dried soils of the former lacustrine bottom.

\section{Study site 2}

This study site is located to the north of the Sumowskie Lakes system (Fig. 1). Partially, it includes fragments of the former bottom, where just like in case of the study site no. 1, gyttja-moorsh soils prevail developed from the lacustrine sediments (Fig. 5).

The dry-out stronger in this area compared to the sections located in the southern part of the Sumowskie Lakes system is reflected in specific wedge structures found in gyttja-moorsh soils. There are also black earths in this area, developed from tills in the eastern part and pararendzinas, rich in calcium carbonate, which developed on the kame hills of the study site western part. Another type is made up by deluvial soils in the form of a narrow strip at the base of these hills. The prevailing vegetation communities herein are meadows - Arrhenatheretum elatioris and Lolio-Cynosuretum growing on low gyttja-moorsh soils and black earths. The kame hills occupy communities of Lamio-Veronicetum and Vicietum tetrasperme, typical for field cultivation. In the lowest section, where the gyttja-moorsh soils dehydrations finds the worst reflection, there is a mosaic of rush and willow shrubs identical with the soil covering the former lacustrine bottom in the study site no. 1 - Phragmitetum australis/Salicetum pentandro-cinereae.

The occurrence of specific systems of soils and vegetation cover within the area of the former bottoms of the Sumowskie Lakes and their immediate vicinity also found confirmation in the investigations of Gonet et al. (2010).

\section{Study site 3}

This site is located in the western part the Sumowskie Lakes catchment area (Fig. 1). The area covers vast peaty kettle hole (peat-moorsh and peat soils), plus its immediate surroundings made of sandy glaciofluvial sediments (rusty soils).

The area surrounding the kettle hole is occupied by mineral soils developed from sandy sediments - gley soils at the edge of the kettle, and rusty soils in the higher lo- 


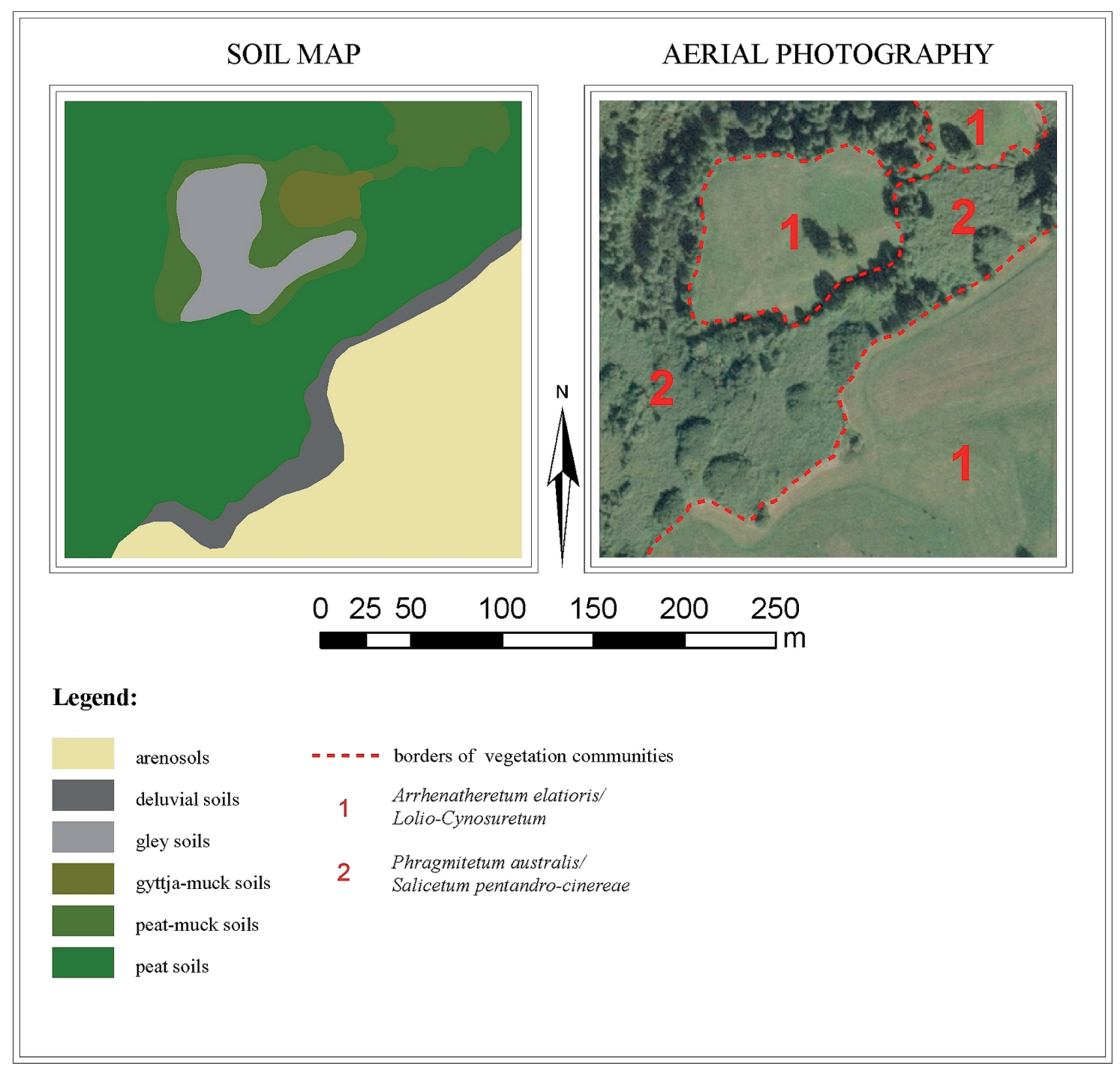

Figure 4. Field test No. 1

cated vicinity (Fig. 6). The vegetation of this study site is very diverse. The natural forest vegetation communities have been transformed as a result of local forestry and land improvement works resulting in dehydration of the habitats. The vegetation is arranged in strips corresponding to individual types of soils. The lowest peat soils are covered with a mixed community consisting of the alder, natural in the peat soils, and pine (Pinus sylvestris - Alnus glutinosa), which was brought here, while peat-moorsh soils, more dried-out, are covered with deciduous forest with the majority of birch (Betula pendula - Urtica dioica). The mineral soils are mainly covered with pine. On gley soils, relatively rich in the organic matter, it produces a community with a nitrofile nettle (Pinus sylvestris - Urtica dioica), however on the uppermost rusty soils, it is accompanied by the blackberry (Pinus sylvestris - Rubus plicatus). The occurrence of the pine forests on the rusty soils in vicinity of the peat bog of Tomki was also proved by Ścibor (2005).

\section{Discusion}

Sumowskie lake catchment is a very good example of the evolution of the soil cover and associated vegetation cover in the northern Polish agricultural landscape. The natural process of disappearance of the lake was accelerated by human activities (for example by drainage) in order to obtain new land for cultivation. Lowering the groundwater level determine the possibility of using "new areas" by man. In areas of shallow groundwater occurrence (up to $50 \mathrm{~cm}$, with groundwater is often found on the surface), in principle, it is impossible to conduct any crop. There devel- 


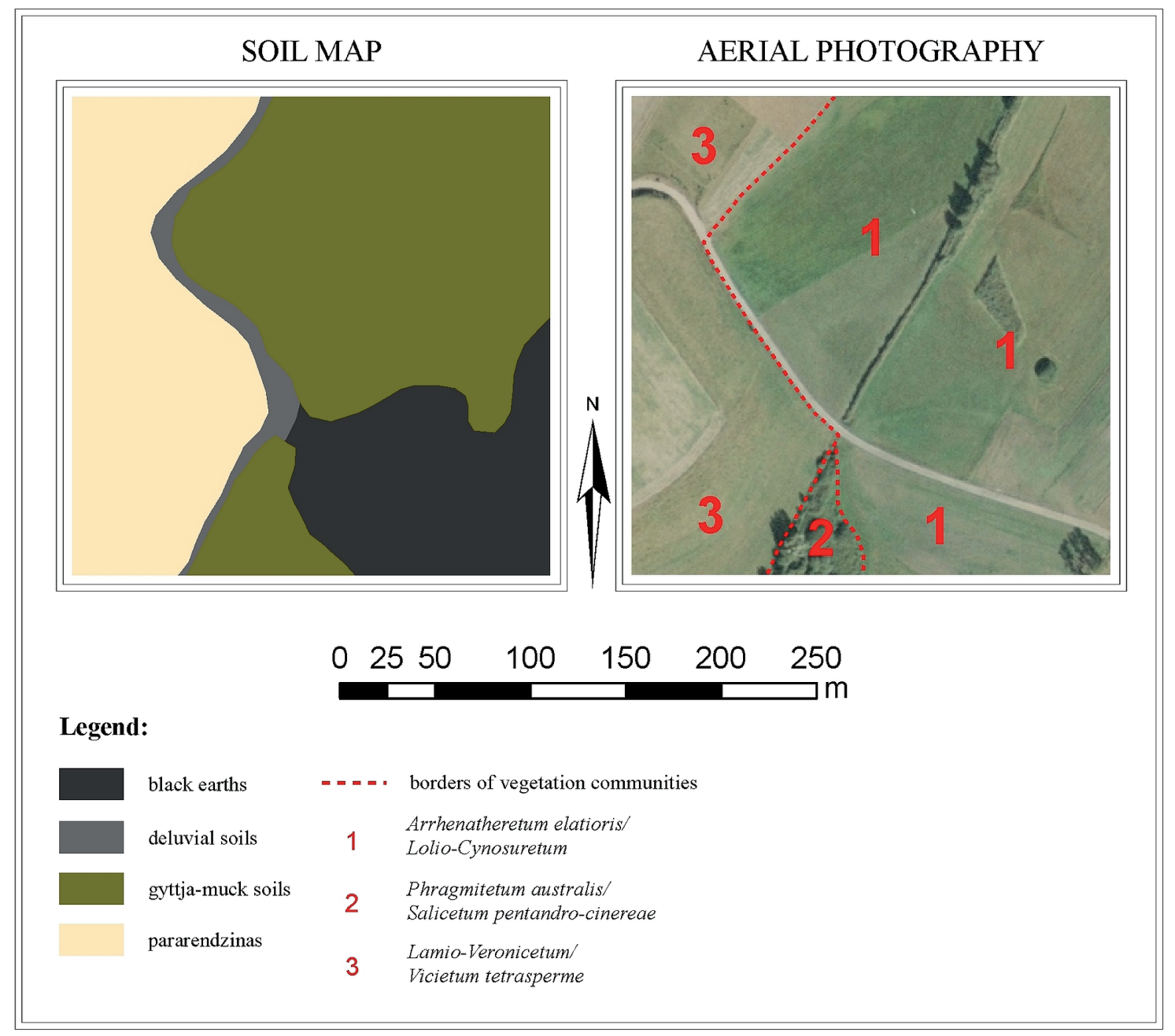

Figure 5. Field test No. 2

oped a natural plant communities. Wherever groundwater levels decreased more, the man introduces anthropogenic communities - meadows, pastures, and on heavily drained areas - fields.

The most important property used for photointerpretion in test areas was vegetation cover. In the catchment of disappearing Sumowskie lakes dominate unnatural, created or altered by human activity plant communities. Following proportions of occurring variants of land use (1976) were established by Okrucińska (2009):

- arable land and wasteland - 1115 ha,

- meadows and wetlands - 314 ha,

- forests - 342 ha.

The greatest species diversity among non-forest communities in Brodnica Landscape Park occurs within a peat-meadow ecosystems (Burak et al. 2005b). Based on the "Botanical Inventory BPK" of 2005, they appointed five separations of this type of habitat, and the three of them represent rush communities, while the other are reed-alder and reed-willow mosaics.

The natural vegetation of the study area established by Matuszkiewicz (Map of Potential Vegetation of Poland 2008) are Carici elongate-Alnetum, Fraxino-Alnetum and Tilio-Carpinetum habitats. The first two represent the communities of lowland riparian forests that occur on slight marshy habitats. The third community is the variation of broadleaf forest, potentially occurring at higher altitudes on the edges of the study area (Matuszkiewicz 2005).

Currently, the dominant communities in the immediate vicinity of Sumowskie lakes are Phragmitetum australis, Salicetum pentandro-cinerae and Ribeso nigri-Alnetum. In surroundings of reservoirs occur crop production communities such as Lamia-Veronicetum or Vicietum tetrasperme and meadow ones such as Arrhenatheretum elatioris and Lolio-Cynosuretum (oral information by Andrzej Dziamski, Department of Botany and Ecology, UTP Bydgoszcz). 


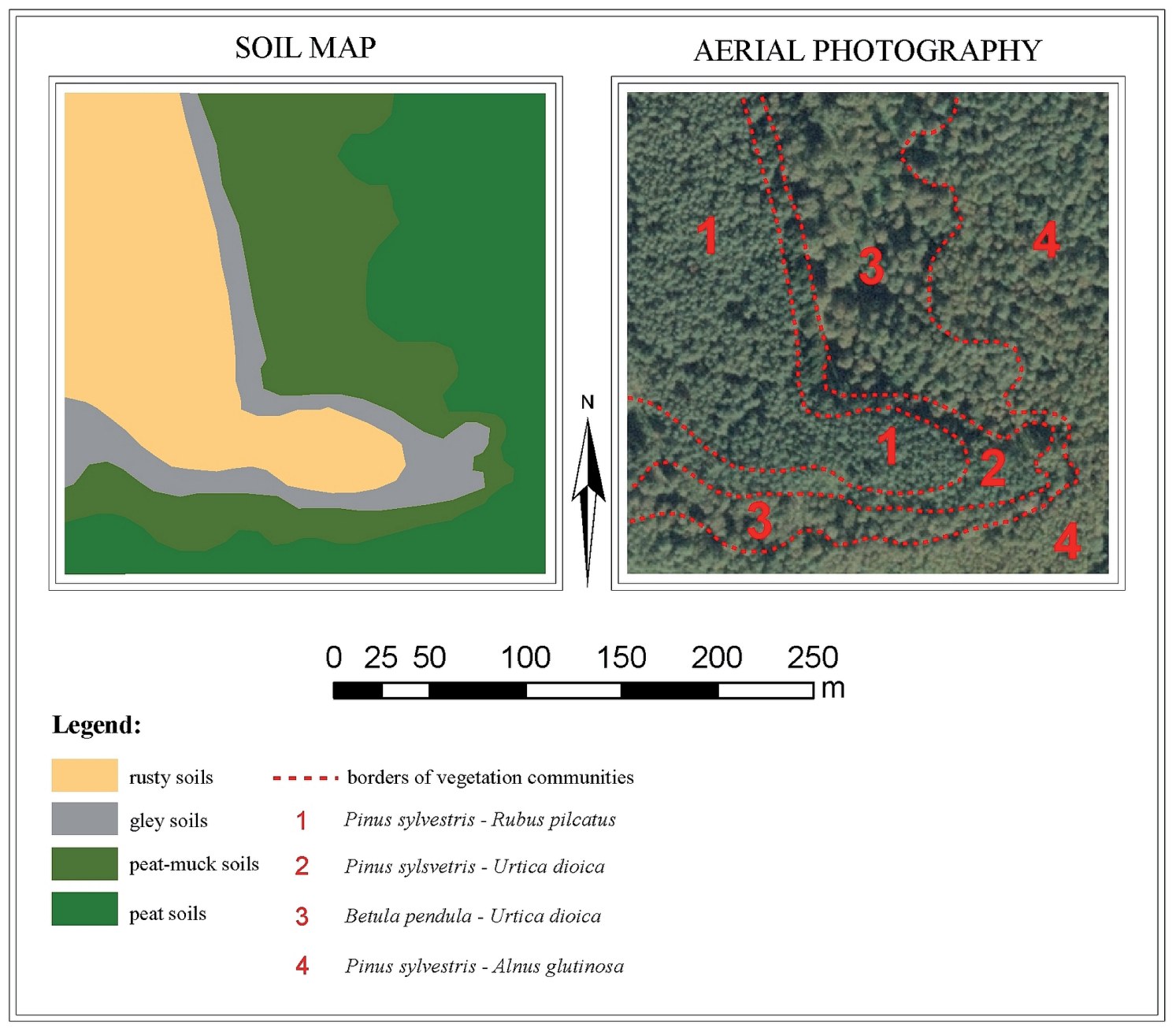

Figure 6. Field test No. 3

The types of the soil cover structure defined for the test areas on the basis of a soil maps are among the strip-ordered (test area 3 ) or irregular-spotty structure (test area 2). The wide variation in the soil cover in the test area 1 , reflected also in a mosaic of vegetation cover (elements of both a structured and irregular crimson spotted) helped distinguish multi-component and disorganized type of the soil cover structure.

\section{Conclusion}

The obtained results confirm the high usability of the cartographic materials such as aerial photographs and topographic maps for studies on specific areas such as the vicinities of dwindling lakes. The interpretation of colourful photographs enabled the large-scale cartographic studies for the areas such as dwindling kettle water bodies.
The most important variable (intermediate property) herein is the diverse vegetation cover. The ranges of individual vegetation communities correspond to relevant soils. Nonetheless, it must be stressed that the soil mapping based merely on the aerial photos analysis is not feasible, even though it largely contributes to the field studies and very often accelerates the works.

\section{Acknowledgements}

This study was financed by the National Science Centre $(\mathrm{NCN})$ of Poland in the form of project no. N N305 283337. 


\section{References}

Bednarek R. \& Prusinkiewicz Z., 1997, Geografia gleb [Geography of soils], Wydawnictwo Naukowe PWN, Warszawa.

Bednarek R., Sewerniak P. \& Gruba R., 2007, Analiza porównawcza czarnych ziem i gleb murszastych na terenie Brodnickiego Parku Krajobrazowego [Comparative analysis of black earths and mucky soils in the area of the Brodnica Landscape Park], [in:] Marszelewski W., Kozłowski L. (eds.) Ochrona i zagospodarowanie dorzecza Drwęcy, t. 1, Toruń: 19-31.

Białousz S., 1999, Zastosowania teledetekcji w badaniach pokrywy glebowej [Applications of remote sensing in the study of soil cover], [in:] Zawadzki S. (ed.) Gleboznawstwo, PWRiL, Warszawa: 511-512 and 526-538.

Burak S., (ed.) 1994, Stan środowiska w województwie toruńskim w 1993 roku [State of the environment in Toruń voivodship in 1993], Biblioteka Monitoringu Środowiska, Toruń.

Burak S., Flanz S., Kurowska I. \& Pawski A. 2005a, Ekosystemy wodne [Water ecosystems], [in:] Plan Ochrony BPK do roku 2025, część II, Toruń: 9-25.

Burak S., Flanz S., Kurowska I. \& Pawski A. 2005b, Walory florystyczne [Flora], [in:] Plan Ochrony BPK do roku 2025, część II, Toruń: 26-85.

Ceynowa-Giełdon M., 1984, Roślinność, [in:] R. Galon (ed.). Województwo toruńskie. Przyroda - ludność i osadnictwo - gospodarka [Toruń voivodship. Nature - population and settlement - economy], PWN, Warszawa-Poznań-Toruń: 207-210.

Ciołkosz A., Miszalski J. \& Olędzki J. R., 1999, Interpretacja zdjęć lotniczych [Interpretation of aerial photographs], Wyd. Nauk. PWN, Warszawa: 305-356.

Fuller R. M., Cox R., Clarke R. T., Rothery P., Hill R. A., Smith G. M., Thomson A. G., Brown N. J., Howard D. C. \& Stott A. P., 2005, The UK land cover map 2000: Planning, construction and calibration of a remotely sensed, user-oriented map of broad habitats, International Journal of Applied Earth Observation and Geoinformation 7: 202-216.

Furmańczyk K., 1980. Zarys fotointerpretacji [Outline of photointerpretation], Skrypt uczelniany UG [Gdańsk University script], Gdańsk: 248-249.

Gonet S., Markiewicz M., Marszelewski W. \& Dziamski A., 2010, Soil transformations in catchment of disappearing Sumówko Lake (Brodnickie Lake District, Poland), Limnological Review 10 (3-4): 133-137.

Kalinowska K., 1961, Zanikanie jezior w Polsce [Lake disappearance in Poland], Przegląd Geograficzny 23 (3): 511-518.

Marszelewski W., 2005, Zmiany warunków abiotycznych w jeziorach Polski Północno-Wschodniej [Changes of the abiotic conditions in the lakes of north-east Poland], Wyd. UMK, Torun.

McBratney A. B., Mendoça Santos M. L. \& Minasny B., 2003, On digital soil mapping, Geoderma 117 (1-2): $3-52$.

Niewiarowski W., 1995, Główne rysy rzeźby terenu Pojezierza Brodnickiego oraz problem wahań poziomu jezior w okresie późnego glacjału i holocenu [The main features of the relief and the problem of lake level fluctuations during the late glacial and holocene on Brodnica lakeland], [in:] W. Niewiarowski (ed.), Geomorfologia i hydrologia Pojezierza Brodnickiego i Dobrzyńskiego oraz osobliwości przyrodnicze parków krajobrazowych. Przewodnik wycieczki nr 3. 44 Zjazd Polskiego Towarzystwa Geograficznego [Geomorphology and hydrology of Brodnica lakeland and Dobrzyń lakeland and natural curiosities of landscape parks. Tour Guide No. 3 of 44 Congress of the Polish Geographical Society]. Toruń: 17-27.

Okrucińska B., 2009, Zmiany użytkowania gleb w zlewniach zanikających jezior [Changes in soil use in the catchment of disappearing lakes]. Manuscript of master thesis, UMK, Toruń.

Richling A. \& Dąbrowski A., 2005, Typy Krajobrazów Naturalnych 1:1500 000 [Types of natural landscapes 1:1 500 000], [in:] Richling A., Ostaszewska K. (ed.) Geografia Fizyczna Polski [Physical Geography of Poland], Wyd. Nauk. PWN, Warszawa.

Smirnow L. J., 1970. Teoretyczne podstawy fotointerpretacji [Theoretical basis of photointerpretation], PWN, Warszawa. s. 186-188.

Systematic of Polish Soils, 1989, Soil Science Annual 40 $(3 / 4)$.

Szczegółowa Mapa Geologiczna Polski 1:50 000, arkusz 285.0 Brodnica [Detailed geological map of Poland 1:50 000, sheet no. 285.0 Brodnica], available on www. ikar2.pgi.gov.pl.

Szczegółowa Mapa Geologiczna Polski 1:50 000, arkusz 247.0 Skarlin [Detailed geological map of Poland 1:50 000, sheet no. 247.0 Skarlin], available on www. ikar2.pgi.gov.pl.

Ścibor A., 2005 Charakterystyka gleb kemów Brodnickiego Parku Krajobrazowego [Characteristics of soils of kames in Brodnica Landscape Park], Manuscript of master thesis. UMK, Torun.

Van Reeuwijk L. P., 2006, Procedures for soil analysis. $7^{\text {th }}$ Edition. Technical Report 9, ISRIC - World Soil Information, Wageningen, Netherlands.

Zielski A., 1978, Zespoły leśne Pojezierza Brodnickiego oraz wpływ na nie gospodarki leśnej i turystyki [Forest communities of Brodnica Lakeland and the effect of forest management and tourism], PWN, Warszawa-Poznań-Toruń: 77-79. 